\title{
Between India and the Indies: German mercantile networks, the struggle for the imperial crown and the naming of the New World ${ }^{1}$
}

\author{
Renate Pieper \\ Chair in Economic and Social History, History Department, Karl-Franzens-University Graz, Attemsgasse 8, A-8010 Graz Austria
}

\begin{abstract}
Submitted: 30 April 2014. Accepted: 28 May 2014
\end{abstract}
\begin{abstract}
In 1507, the excitement over the publication of the Mundus Novus led to the naming of a new continent on the map, a globe and a learned treatise as an appendix to an edition of a work by Ptolemy published in Saint-Dié, Lorraine. Network analysis of the cities where the broadsheet Mundus Novus, attributed to Amerigo Vespucci, appeared shows that the text was mainly published in German mercantile cities, especially Augsburg and Nuremberg between 1504 and 1506. There is strong evidence that this text about the voyages of Amerigo Vespucci was primarily issued to raise money in order to finance German mercantile investments in the Portuguese fleet to Asia in 1505-1506. In 1507, the map and the globe with the new name for the New World demonstrated the riches that the members of the Diet of Konstanz might obtain if they supported Maximilian in his expedition to Italy and his quest for the imperial crown. Thus, the struggle between Maximilian I and Louis XII for the title of Holy Roman Emperor and the need for investment in German trade with Asia determined the invention of America.
\end{abstract}

KEYWORDS: Maximilian I ; Louis XII; Holy Roman Emperor; Konstanz; Augsburg; Nuremberg

Citation / Cómo citar este artículo: Pieper, Renate (2014). "Between India and the Indies: German mercantile networks, the struggle for the imperial crown and the naming of the New World". Culture \& History Digital Journal, 3(1): e003. doi: http://dx.doi.org/10.3989/chdj.2014.003

RESUMEN: Entre la India y las Indias: redes mercantiles alemanas, la lucha por la corona imperial y el nombramiento del Nuevo Mundo.-El gran número de impresos sobre el "Mundus Novus" descubierto por Amerigo Vespucci incitaron el nombramiento del nuevo continente en un globo, un mapa y un tratado de geografía junto con una edición de la obra de Tolomeo impresos en Saint-Dié en 1507. El análisis de las redes de las ciudades en donde se publicó el "Mundus Novus" muestra que este texto fue impreso sobre todo en ciudades mercantiles alemanas, especialmente en Augsburgo y Nuremberg entre 1504 y 1506. Esta ola de publicidad se debió seguramente a las necesidades financieras de las casas mercantiles de la región para poder participar en una flota portuguesa a la India en 1505-06. En 1507, el mapa y el globo que llevaban un nombre nuevo para un nuevo mundo mostraban las riquezas que los participantes de la dieta imperial de Konstanz pudieran ganar apoyando a Maximiliano de Austria en su expedición a Italia para recibir la corona imperial. La contienda entre Maximiliano I y Luis XII por obtener el título de Emperador así como las inversiones de las casas mercantiles alemanas en el comercio con Asia determinaron la invención de América.

PALABRAS CLAVE: Maximiliano I; Luis XII; corona imperial; Konstanz; Augsburgo; Nuremberg

Copyright: (C) 2014 CSIC. This is an open-access article distributed under the terms of the Creative Commons AttributionNon Commercial (by-nc) Spain 3.0 License.

America was invented in Saint-Dié, Lorraine in 1507 (O'Gorman, 1995; Sanz, 1959) and immediately met with resounding success. In southern Germany, humanists copied and recopied the sketch of the new continent and its new designation. In contrast, the creator of the map of the new continent, cartographer Martin Waldseemüller, omitted the name America from the maps he printed from 1513 onwards. Nonetheless, America was already firmly attached to the New World in the German humanist consciousness. ${ }^{2}$ This story is very well known, 
but certain matters are still the subject of debate: why German humanists were much more familiar with the voyages of Amerigo Vespucci than with those of Christopher Columbus; why they retained the new name even when its inventor had dropped it; and why it was humanists from southern Germany, and not Spanish, Portuguese or Italian scholars, who determined the name of the New World.

In order to answer these questions, the transfer of information between the southern Atlantic and southern Germany which led to the dissemination of the deeds of Amerigo Vespucci will be analysed. A reconstruction of the networks of printed media will be crucial to our understanding of why Vespucci received such enormous attention in contrast to other contemporary explorers. In order to place the publicity gained by the voyage of Vespucci in a broader context, it will be compared with the distribution of news about similar events, i.e. the first voyage of Columbus, as its most important predecessor based on number of publications. Comparison of the distribution of information about the first voyages of Columbus and Vespucci thus forms the basis of the following analysis. The spread of these messages will be studied mainly for the German Empire and Southern Europe, the centres of the printing press in Europe. Although ultimately the naming of the New World was a long process, its initial years will be the focus of the present study.

Historiography has followed the 1958 argument of Edmundo O'Gorman that America was invented and not really discovered (O'Gorman, 1996; Gil, 1989; Pietschmann, 2007: 367-389). The naming was the work of two German humanists from the University of Freiburg: Mathias Ringmann, a young scholar, and Martin Waldseemüller, an outstanding cartographer. In 1507, they published an edition of Claudius Ptolemy's Geography in Saint-Dié, Lorraine, a centre of learning recently created by Duke René II of Lorraine. Ringmann added an account of four voyages to Brazil attributed to Florentine humanist Amerigo Vespucci to Ptolemy's work. Furthermore, Ringmann attached a geographical commentary in which he suggested calling the recently discovered landmass in the southwestern Atlantic after Vespucci's first name: America, an alliteration with Asia and Africa. The cartographer, Martin Waldseemüller, designed a large world map and a small globe, both printed as woodcuts. On the map and globe, the territories in the southwestern Atlantic were named America. This published sample from 1507 - the world map, the globe, the account of the voyages and the humanist commentary - determined the name of the New World. Lehmann (2010) offers a new edition and translation of Ringmann's text. And although this information is widely known, it remains unclear why Ringmann and Waldseemüller chose the accounts of Vespucci rather than those of Columbus.

Historians have stressed that the images attributed to the New World had been deeply rooted in European culture since antiquity. The same monsters and giants that appeared in the grotesques of Renaissance gardens were used in descriptions of the Americas. In addition, these perceptions seemed to have been rather long-lasting and static (Elliot, 1970; Pagden, 1993; Siraisi, 1992). The same happened with the cartographic image by Martin Waldseemüller and especially the naming of the new continent. The reasons why changes occurred so slowly or not at all still remain obscure.

Another point that has been brought to the attention of historiographical analysis was the importance of German publications concerning the Americas, which were rather numerous, especially during the first decades of the $16^{\text {th }}$ century (Hirsch, 1976: 537-558). The same applied to the naming of the New World, which happened within the sphere of the German humanists, but it is rather unclear why the German scholars at Saint-Dié were so influential, as they had no direct relation to the Iberian Peninsula and even less to the southern Atlantic.

Possible reasons why America was forever named after Vespucci at Saint-Dié in 1507 may be identified by comparing the dissemination of news about the Columbus and Vespucci voyages. The networks of the different editions will be reconstructed and analysed in chronological order, with short references to the circulation of manuscripts and maps in each case. This comparison of the networks for printed broadsheets needs to be preceded by a few general considerations regarding the economic aspects of printing in the early modern period.

The printing press has been regarded as an agent of considerable change in early modern times and especially as a means to further capitalism in the information business (Eisenstein, 1983). This historiographical concept of the 1970s and 1980s has been contested since the turn of the $21^{\text {th }}$ century (Bethencourt and Egmond, 2007; Vivo, 2007; Infelise, 2002; Bouza, 2001). Recent studies stress the market orientation of manuscript production in numerous offices, where scribes copied and recopied the latest news based on demand from subscribers and readers. In contrast, printers needed large preliminary investments in paper, manpower and machinery. These were not usually paid for by readers in advance, but by persons interested in disseminating information, or in some cases, like manuscripts, by subscribers. Thus, printed publications were to a great extent financed by those concerned to exercise influence in the public sphere. Because this was one objective of printing, it is crucial to determine the parties interested in financing the broadsheets discussing the new continent and its naming.

The first look at the new continent was offered by Christopher Columbus when he returned from his first voyage of exploration to the western Atlantic in February of 1493. Immediately upon arriving at Lisbon, he sent several letters to the Catholic Monarchs and his own financial backers in Barcelona. Columbus's handwritten letters were copied and disseminated through manuscripts in Spain and Italy (Pieper, 2000). The hub of the network for the distribution of the handwritten letters was the Castilian-Aragonese court 


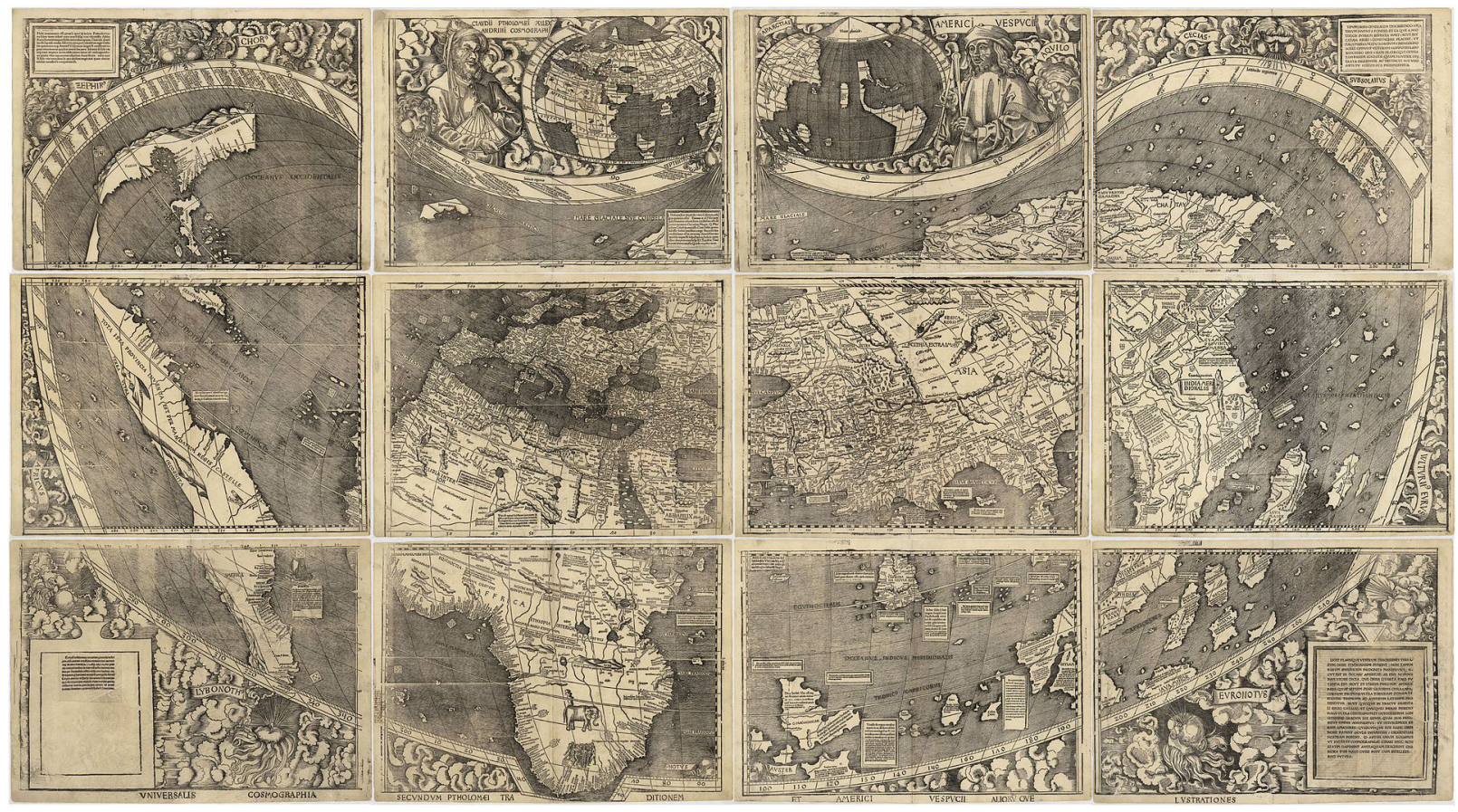

Martin Waldseemüller, Universalis Comographia, 1507.

This is the first map to include the name "America" and the first to depict the Americas as separate from Asia.

of the Catholic Monarchs. Based on the handwritten correspondence, the first printed Columbus letters and the various editions were published first in Spain and then in Italy, primarily in Rome (Alden and Landis, 1980, vol. 1). From Rome, Italian and Latin publications were mostly distributed through printing houses of German origin. In contrast to the network for the handwritten letters of Columbus, the network of printers was centred in Rome (Diagram 1). Nine editions and references were issued in Rome, and Rome was connected, except in one case, to all the cities where Columbus's letters or references to his explorations were published in 1493. Next to Rome, the "Spanish" court was the most important place in the network, as the first two printings of Columbus's letters were published in Barcelona. In Seville, as early as 1493, a large law book was issued which included a short reference to Columbus's findings. The French participated in the publishing business as well. In Paris, one single printing house issued three editions of the Columbus letters in 1493. Reprints or translations, in some cases even with illustrations, appeared in Antwerp, Leipzig, Basel, Pavia and Florence. Thus, in contrast to the general belief in the prevalence of German printing centres, this was not the case for publication of Columbus's letters and references to him. In 1493, most, i.e. eleven, editions of the letters or references to his endeavours in the southwestern Atlantic were published in Italy, three on the Iberian Peninsula, three in France and only two in Germanspeaking regions and one in Flanders.
The structure of the network implies that the publications were intended to serve as propaganda for the Catholic Monarchs. At least one of the publications from Barcelona was ordered, published and paid for by the Castilian-Aragonese crown (Rumeu de Armas, 1989). In the case of the Roman publications, specific data are lacking, but many of the titles suggest that the propaganda in Rome would have supported the position of the Catholic Monarchs in the Roman and Vatican public spheres. At the same time, the Castilian-Aragonese monarchs obtained several papal bulls from Aragonese pope Alexander VI to be used to reverse the Treaty of Alcáçovas (1479) with Portugal. According to this older treaty, the Castilians were required to avoid exploration south of Cape Bojador, near the Canary Islands. After the return of Columbus, the Treaty of Alcáçovas had to be replaced if the Castilian-Aragonese monarchs wanted to authorize further expeditions in the southwestern Atlantic. The use of these publications as propaganda proved to be effective, as the Spanish Monarchs obtained favourable papal bulls and were able to sign a new treaty with Portugal after just one year of negotiations, in 1494. The new Treaty of Tordesillas allowed the Castilians to explore territories in the western Atlantic even if they were located in the south. After 1493, publications which discussed the account of Columbus's travels at length ceased on the Iberian Peninsula. Up to 1496, only three editions with an increasing number of engravings were issued by printing houses in northwestern Europe. Thus the first publications on the Columbian voyages must be attributed mainly to the political interests of the 


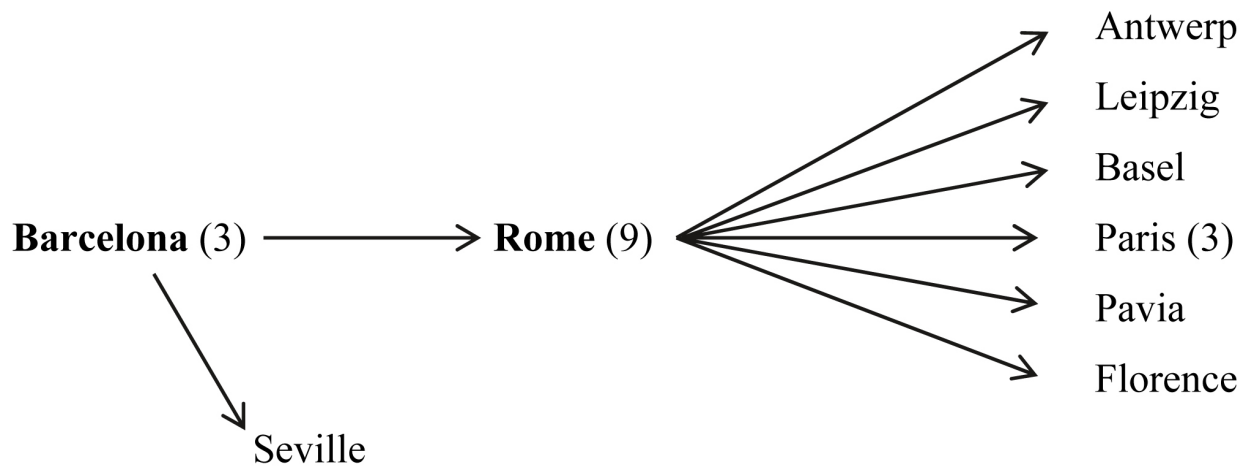

Diagram I. Network of cities where references of the first Columbian expedition were published in 1493 Source: John Alden and Dennis C. Landis (editors), European Americana. A Chronological Guide to Works Printed in Europe Relating to the Americas, 1493-1600, vol. 1, New York, 1980. Database available online: European Views of the Americas: 1493 to 1750 , European Americana: A Chronological Guide to Works Printed in Europe Relating to the Americas, 1493-1600, EBSCOhost. Numbers in brackets refer to the number of editions.

Castilian-Aragonese Catholic Monarchs. The dissemination of information about the first Columbian expedition by means of the printing press sharply contrasts with the current historiographical hypothesis: In the case of Columbus's first voyage, there was no naming according to humanist concepts of classical antiquity, rather the Columbian labelling responded to contemporary geopolitical interests. The publications from Germanspeaking areas were vastly outnumbered by those from Italy. Columbus's first published letters were not destined to have a long-lasting effect, but they were an effective use of fresh information in the ongoing political and commercial struggle between Castile and Aragon on the one hand and Portugal on the other.

Columbus's efforts to reach Asia seemed to have been successful in 1493. But between 1494 and 1500, after two subsequent Columbian voyages, quite a number of other explorers and the first expedition of Vasco da Gama to India (1497-1499), the Mediterranean powers realized that a new landmass, an island or continent, had been found in the southern Atlantic. Since reaching the Orinoco in 1498, Columbus himself believed that the northern territories in the western Atlantic were connected to Asia in the northwest, whereas the landmass he had seen in the southwestern Atlantic was described by him as another world, different from the ones known to Europeans since antiquity (Rumeu de Armas, 1989; Varela, 1984: 282; Gil, 1982: 487-502). In 1500 , shortly after the return of Columbus and Vasco da Gama, humanist Peter Martir de Anghiera wrote to Rome from the "Spanish" court regarding "De orbem ... novo" and stated that the Castilians sailing west found naked inhabitants, whereas the Portuguese had followed the route of their spice trade to the south (Lunardi, Magioncalda and Mazzacane, 1988: 92-95). In 1500-1501, the Portuguese dispatched their own transatlantic expeditions: to the south under the command of Pedro Álvares Cabral and to the north under Miguel and Gaspar Corte Real. After the return of these voyages of exploration, the opinion circulated in Lisbon that the territories found in the northwestern and southwestern Atlantic were probably linked to each other but were certainly different from Asia (Berchet, 1892-1893, vol. 1: 87). Therefore, Columbus set out on his last expedition in 1502 in order to find the strait in central America which was believed to separate the southern island or continent from the northern one, and would open up a passage to India.

The Columbian conception of geography in 1500-1502 was painted by Juan de la Cosa as a parchment mappa mundi. ${ }^{3}$ But La Cosa, a pilot on the first Columbian exploration, did not offer any indication as to whether there was a strait or an isthmus separating or uniting the southern and northern parts of the newly found landmasses. Instead, La Cosa painted the figure of Saint Christopher in its place. Thus, the crucial question remained open for Portugal and Castile. Due to the uncertain situation in the western Atlantic, the African territories became essential for access to India in the commercial and political struggle between Portugal and Castile. Therefore, La Cosa depicted the western coast of African recently explored by the Portuguese as the most valuable territories in the southern Atlantic and a sort of grey landmass blocked the direct route to India in the west.

Between 1502 and 1504, at the same time as Columbus's fourth voyage, various manuscript maps designed first in Lisbon and later copied in Genoa circulated across Europe. They reached Flanders, southern Germany, Austria and France. In Antwerp, Matthäus Lang, archbishop of Salzburg and secretary to Emperor Maximilian I, ordered a copy of one such Portuguese map. Another map reached Augsburg. The Welser family, a former German merchant house, still holds a fragment of a mappa mundi on parchment which shows the European image of East Asia between 1502 and 1504. The most famous of the Portuguese mappae mundi is the one bought by merchant Alberto Cantino in Lisbon for Duke Hercules of Ferrara in $1502 .{ }^{4}$ The centre of 
this large and richly illustrated map on parchment shows Africa and its wealth. The two major cities depicted are Venice and Jerusalem. Portuguese explorations along the Brazilian coast are highlighted as well. Thus, on this manuscript map designed in Lisbon, the Portuguese promoted their own achievements in the southern Atlantic. Unlike the manuscript map made by La Cosa, Cantino's map on parchment, along with the other known maps of Portuguese-Genoese origin, showed a strait between the northern and southern lands in the western Atlantic. Thus, they disseminated the geographical conception of Columbus from 1498 that there was an island or continent in the western part of the Southern Hemisphere that was distinct from the northern territories explored in the western Atlantic, and thus the southern island was certainly distinct from Asia. Only the results of the fourth Columbian voyage could prove which idea was valid: an isthmus or a strait between the south and the north. The connection between the newly found lands and Asia in the northwest would remain an enigma for centuries (Milanesi, 1992: 19-50).

One year later, in 1503, the European balance of power would change. Castile and Aragon had dynastic problems. The heiress of Castile, Joanna, was married to the duke of Burgundy and heir to the Holy Roman Emperor (Aram, 2005). Thus a foreign king would inherit Castile in the near future. In the first half of 1503 , Aragon was not very successful in its struggles with France in Italy. Milan, Florence and a larger part of Naples were under French control (Tewes, 2011: 517602). And in 1503, Aragonese pope Alexander VI, who had issued the bulls in 1493, died. After the short interregnum of Pius III, Julius II, a sworn enemy of Alexander VI, was elected in the same year. And even worse for Castile and Aragon, Portugal had regained its power under its new king Manuel I and was equipping its fifth fleet to India.

Under these circumstances, in 1503, a Latin broadsheet was published in Paris describing a minor Portuguese voyage of exploration to the Brazilian coast. The small fleet had returned to Lisbon in 1502. The supposed author of the travel account, written in the form of a letter, was a member of the crew, Florentine merchant and mariner Amerigo Vespucci. At that time, Vespucci lived alternatively in Lisbon and Seville. The addressee of the published letter was the recently deceased, renowned member of the Florentine Republic, Pier Francesco de Medici, who had initially been supported by France. The Parisian broadsheet attributed the description of a voyage to the southwestern Atlantic where a new world "Mundus Novus" - had been found to Amerigo Vespucci. ${ }^{5}$ This term referred to a report by Columbus, who in 1498, on his arrival at the Orinoco, had used the designation "another world" - "Otro Mundo" - in southwestern Atlantic. The broadsheet attributed to Vespucci published five years later in Paris stressed the anthropophagy and the nakedness of the inhabitants of these new territories. The description of male and female personal adornments is very extensive and the women are reported to be especially lascivious. Descriptions of the constellations of stars south of the equator are sprinkled throughout the text. Nonetheless, the geographical references in the broadsheet are so vague that even today the regions explored by this expedition remain unclear. What is most astonishing, the broadsheet does not mention the leader of the fleet. Even the descriptions of the fauna are somewhat hazy. The various colours of the parrots were described with an erroneous allusion to Polycleitus, who is considered the master of antique sculpture and not painting.

In sharp contrast to the earlier Columbian letters, the subjects mentioned in the Mundus Novus broadsheet were not really new. Anthropophagy and lasciviousness were classic European clichés. Nakedness and large personal adornments in the ears, lips and nose with precious stones and bones were also known from Africa. Finally, the constellations of stars in the Southern Hemisphere had already been familiar to Europeans for half a century (Vogel, 1992: 53-104). Nor did the Vespucci letter stress the Portuguese endeavours or the accomplishments of the leader of the expedition. Rather, it described the adventures of an Italian member of the crew. In contrast to other travel accounts, which described their points of arrival as precisely as possible in order to secure new territories, the broadsheet attributed to Amerigo Vespucci offered only uncertain geographical data. In 1503, the broadsheet was not issued in Portugal, the fleet's point of arrival, or in Florence, even though the deceased addressee of the printed letter had lived in that city. Instead, the first edition of the Mundus Novus was printed in Paris one year after the return of the expedition.

This bizarre situation notwithstanding, the broadsheet attributed to Amerigo Vespucci had resounding repercussions: It was reprinted time and again, especially in Upper German merchant towns, first in Augsburg and later in Nuremberg and many other cities. In Basel and Strasbourg, illustrations were added, and recopied in Augsburg and Nuremberg. The success of the broadsheet was astonishing, in so far as it was reprinted only twice in Italy, in Venice and Rome, and was not printed at all on the Iberian Peninsula.

The dissemination of manuscript information on the Vespucci expedition is less well documented. The only references to the voyage are the letters attributed to Vespucci. The authenticity of surviving manuscript copies is still a matter of debate and there are serious doubts about the authorship of the printed versions (Delgado Gómez, 1993: 3-20). Nonetheless, some letters must have circulated between Lisbon, Florence and Paris mentioning the name Vespucci as a participant in a Portuguese expedition to the southern Atlantic. This information must have been used as source material for the 1503 compilation of the Paris broadsheet.

Due to this uncertain situation, the parties interested in printing the broadsheets concerning the Portuguese expedition with an unknown leader described by a 
Florentine crew member are unknown, but publication details for the Mundus Novus offer some hints. French interests in the Atlantic must have been responsible for the first edition in Paris. In 1503, French troops were in Italy and on their way to Naples. Florence once again came under French influence. This may have extended the distribution of the written account describing the Portuguese expedition to the southern Atlantic, which circulated between Florence and Paris. In addition, the French crown tried to join the group of Atlantic explorers. Also in 1503, French nobleman Paulmier de Gounville set sail from Honfleur and probably reached Brazil. He returned in 1505, without any financial profits but accompanied by the son of an Indian chief (PerroneMoisés, 1996: 84-93).

In contrast to Columbus's first letter, which was republished 17 times in the first year of its appearance, no second edition of the Mundus Novus is known from 1503. However, between 1504 and 1506, the enormous figure of 28 editions of the Mundus Novus were published in Europe. These even outnumbered the success of the first Columbus letter, which had been issued 22 times between 1493 and 1496. Whereas almost all editions of Columbus's letter appeared in 1493 and publication declined considerably over the following three years, quite the opposite happened with the first Vespucci letter. Only 1 edition was published in 1503 and 4 editions were issued in 1504, but most appeared later: 14 editions in 1505 and 10 in 1506. Thereafter, publication of the first Vespucci letter virtually ceased for a while.

Publication of the Columbus and Vespucci letters differed not only in timing, but also in geographic distribution (Diagram 2). The centre of the network of publications was Augsburg, where the most (five) editions of the Mundus Novus appeared. The Augsburg editions were connected to five other places which issued Vespucci's letter. Paris held a similar position to Augsburg. The printings started in Paris and therefore there were connections to six different places that reprinted the Vespucci story. Strasbourg, Basel and Nuremberg followed Paris and Augsburg in importance with regard to the dissemination of the Mundus Novus. The Strasbourg and Basel publications relied directly on the first Paris edition, whereas in Nuremberg, printers used publications from either Basel or Rome. Other editions were issued in Cologne and Antwerp, as well as central Germany, i.e. in Leipzig, Magdeburg, Rostock and Munich. Only two editions appeared in Italy, in Venice and Rome. In 1505, readers in Pilsen received a copy of Vespucci as well. In assessing the geographic distribution of the Mundus Novus, it is striking that there were no publications on the Iberian Peninsula and only two editions in Italy, none in Florence. Most of the printings occurred in German-speaking areas. Thus, the first Vespucci letter is like a model for a scientific view of early publications on the Americas: most broadsheets were issued in German-speaking areas, the publications used classic images like anthropophagy and the origins of the Vespucci letter are unclear. Following the words of O'Gorman: an invention, a work of fiction.

The reason for these extraordinary differences between the Columbus and Vespucci letters might be approached by further analysing the timeline and relating it to the geography of the Mundus Novus publications. The vast majority of the 23 editions appeared in commercial cities, with the only copies published in political centres being from Paris, Rome and Munich. Therefore, in contrast to the first Columbus letter, the publishers of the first Vespucci letter must have had a strong mercantile background, as well as political interests. In 1504, two publications appeared in Augsburg. The next year, 1505 , the sites of publication were Augsburg (3), Nuremberg (2) and Strasbourg (2). In the latter two cities, additional editions were put out in 1506, with two and one issues, respectively. Moreover, in that same year, printers from Leipzig, who had reprinted an edition of the Mundus Novus from Strasbourg in 1505, published two more editions based on the same publication. Finally, with three re-editions of the original issue, publication returned to Paris in 1506. Thus most editions appeared in the commercial centres of Augsburg, Nuremberg, Leipzig and Strasbourg between 1504 and 1506, and in the political centre of Paris in 1506. From a geographical perspective, the printings between 1504 and 1506 were clearly an issue of the commercial centres of the Rhine Valley, from Basel and Strasbourg to Cologne, and the mercantile and manufacturing centres of Upper Germany, Augsburg and Nuremberg, as well as Leipzig. All of them had connections to the port of Antwerp. 19 editions of the Mundus Novus appeared in these locations, with a peak of 11 publications in 1505 .

In 1505, one Strasbourg edition of the Mundus Novus was published by young humanist Matthias Ringmann. This edition of the first Vespucci letter was given the title "De Ora Antarctica per Regem Portugallie Pridem Inventa", 6 a poem by Ringmann used as a preface to the Vespucci text. At the end of the Vespucci account, Ringmann added confirmation by the Papal notary, who testified to the presence of a Portuguese embassy to Pope Julius II. This certainly referred to a 1505 embassy, in which the ongoing Portuguese voyages to Africa and India were recommended to papal tutelage. The event of the Portuguese embassy was published in a Roman publication from 1505 with the title "Obedientia Potentissimi Emanuelis Lusitaniae Reis .... Ad Julium"? Thus, in 1505, in his Basel edition of the Mundus Novus, Matthias Ringmann closely associated the voyage of Amerigo Vespucci with Portuguese expeditions to Africa and India.

The keen interest in publishing the Vespucci letter, an almost fictional report of a Portuguese voyage to the southwestern Atlantic, might be connected to the increasing commercial importance of the southern Atlantic region after 1503. In that same year, the Catholic Monarchs set up the Casa de la Contratación (House of Trade) in Seville in order to supervise Caribbean affairs and subsequent explorations. Also in 1503, the Por- 


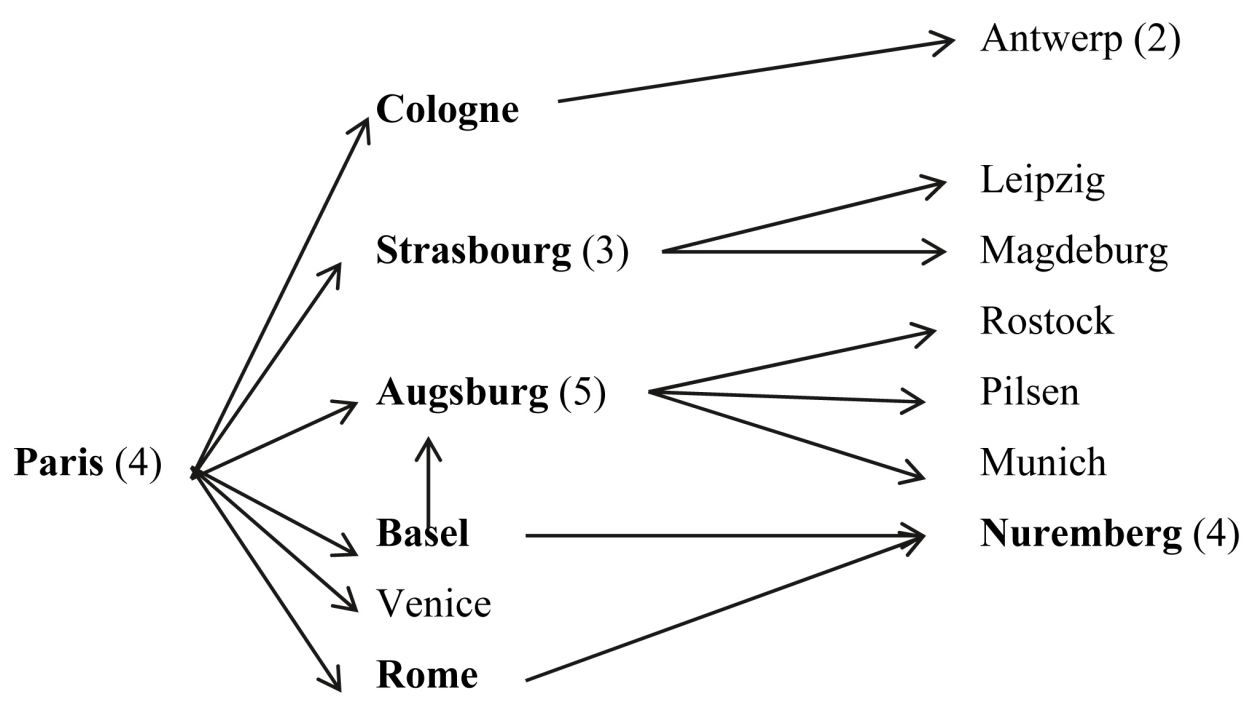

Diagram 2. Network of cities where the Mundus Novus was published, 1503-1506

Source: John Alden and Dennis C. Landis (editors), European Americana. A Chronological Guide to Works Printed in Europe Relating to the Americas, 1493-1600, vol. 1, New York, 1980. Database available online: European Views of the Americas: 1493 to 1750 ,

European Americana: A Chronological Guide to Works Printed in Europe Relating to the Americas, 1493-1600, EBSCOhost. Numbers in brackets refer to the number of editions.

tuguese sent a second expedition to Brazil under the command of Gonçalo Coelho and accompanied by Amerigo Vespucci. Frenchmen Gouneville departed for Brazil as well. But most importantly, in 1503, work began in Lisbon on organizing the Seventh Portuguese India Armada. A very large fleet of 22 ships would sail under the command of Francisco de Almeida, the first Portuguese viceroy to Goa. For the first time, leading houses of business from southern Germany, which had formed a consortium, succeeded in participating in a Portuguese fleet to India with considerable investment (Häbler, 1903: 17-23; Erhard \& Ramminger, 1998: 57-63, 99-110). In 1503, the renowned Wesler merchant family sent Lucas Rem to act as the common agent for the consortium in Lisbon. At the same time, the Welsers obtained a Genoese copy of the large Portuguese world map mentioned earlier. On the 1st of August 1504, the Portuguese crown finally agreed that the German consortium could equip three ships in the fleet. One of the agents for the German merchant houses was Balthasar Springer, who accompanied the "German" cargo to India. Springer originally came from Tyrol, where the Welsers and the Fuggers were involved in silver mining, and silver was one of India's most important exports. In the spring of 1505, the fleet led by Almeida set sail for Africa and India. From January 1506 on, several ships, including the German-owned ships, returned from India with Asian merchandise, especially pepper and spices traded for the German investments. The first German ships arrived at Lisbon in May 1506, and Springer returned to Lisbon with considerable profits in November 1506. The following year, 1507, the flood of Mundus Novus editions ceased.
Analysis of the chronology and geographical distribution of the Mundus Novus letter has shown that these publications were issued mainly in commercial and industrial cities in Upper Germany, the Rhine Valley and Antwerp between 1504 and 1506. Therefore, it might be safely assumed that these propagandistic endeavours were related to the huge investments by the Upper German merchant houses in the seventh Portuguese fleet to India. These wholesale traders and financiers needed to raise funds for their ventures in Asia. When their ships came back with considerable profits, the loans raised for their investments could be paid back and no further printing and fundraising were necessary. The contents of the Novus Mundus letter were sufficiently vague, and so could refer equally to America or Africa and could easily be associated by its readers with the fleet of Francisco de Almeida. Illustrations and the references to anthropophagy and extreme sexual behaviour secured attention for the broadsheet. Furthermore, the mentions of precious stones, bright bones, which might be an allusion to ivory, and parrots referred to riches that might be expected from investment in this trade. Thus the resounding popularity of the first Vespucci letter regarding the new island in the southwestern Atlantic should be attributed mainly to the commercial interests of German merchants in the Portuguese-Asian spice trade.

But there might have been a second group interested in financing editions of the Vespucci letter. None of the three Paris editions which appeared at the end of the flood of publications can be attributed to commercial interests, but must be explained by political reasons and the growing antagonism between the Habsburg and Valois dynasties. On one side, Maximilian I of Habsburg 
was the son of a Portuguese princess, husband of the deceased duchess of Burgundy and father of the heir to those territories. Maximilian had married his two children to Castilian princes. On the other side, the house of Valois sought to improve its own situation in the Atlantic and to seek a Portuguese alliance. Both Habsburg and Valois tried to strengthen their claims to Burgundian territories adjacent to the Rhine Valley. An ambivalent position in the middle of this struggle was held by the Duke of Lorraine, René II, who tried to defend the rest of his inheritance.

When in September 1506, Maximilian I's son Philip the Handsome died in Castile, he left his wife Joanna the Mad and two young sons, Charles and Ferdinand, in Flanders under the custody of their aunt Margaret. Perhaps this uncertain political situation in Castile, Burgundy and the German territories created favourable conditions for three reprints of the first Vespucci letter in Paris. These editions could be used to once more underline the French connection to Portugal and its transatlantic endeavours, and thus strengthen the position of Louis XII in Italy and his claim to the imperial title.

Louis XII's rival, Maximilian of Habsburg, tried to obtain a formal coronation in Rome in order to secure his title as Holy Roman Emperor against France, following the death of his son in September 1506 (Buck, 2008: 35-57). In order to finance his planned expedition to Rome, Maximilian called the German estates to a diet on the 27 th of October 1506 . The estates assembled in Konstanz from the 30th of April to the 26th of July 1507. England, Castile and Aragon, Portugal, Sicily, Hungary and Russia sent special embassies. Before opening the diet, Maximilian had issued broadsheets explaining the international political situation and the need to prevent French King Louis XII from obtaining the imperial title in Rome. In addition, a letter from Pope Julius II was read aloud to the estates during the meeting. In this letter, Julius II requested Maximilian's help against Louis XII. Furthermore, a solemn funeral mass was held for the deceased Philip the Handsome at the Cathedral of Konstanz in June 1507. Despite his propagandistic efforts, Maximilian obtained only scant financial promises from the estates, and only a small part of the financial support actually reached the Habsburg treasury. Nonetheless, Maximilian entered northern Italy in the winter of 1507/08 (Wiesflecker, 1986: 171-175). ${ }^{8}$ As the route to Rome was blocked by Venice, Maximilian made his formal entrance at Trento in a triumphal parade and proclaimed himself the chosen Holy Roman Emperor in February 1508. This title was later confirmed by Pope Julius II.

During the winter of $1506 / 07$, when preparations were being made for the Diet of Konstanz, two humanists, Matthias Ringmann and Martin Waldseemüller, travelled from Freiburg to Saint-Dié-des-Vosges, a city in the territories of Duke René II of Lorraine, which were part of the German Empire. Cartographer Martin Waldseemüller, from the University of Freiburg, was a former student of Georg Reisch, the confessor of Max- imilian I. The young poet and Latinist Matthias Ringmann, who had already published a Vespucci letter, was also a former student of Reisch. In Saint-Dié, Jean Basin de Sandaucourt (Digot, 1856: 134-135), a member of the chapel of Saint-Dié, made a Latin translation of “... delle isole nuevamente trovate", which had been issued at the height of the flood of Mundus Novus publications in Florence in $1505 .{ }^{9}$ In contrast to the Mundus Novus, this new text described four voyages of Amerigo Vespucci. The broadsheet maintained that the Florentine merchant-mariner had participated in two expeditions under the flag of Castile and had taken part in two voyages aboard Portuguese ships. Furthermore, the Florentine publication claimed that Vespucci had made his first voyage to the new continent in 1497 , i.e. even before Columbus reached South America on his third voyage in 1498. In 1506-07, in Saint-Dié, the humanists from Freiburg, Waldseemüller and Ringmann, published Ptolomy's Cosmography and the Latin translation of the text about the four voyages attributed to Vespucci. Ringmann added a text explaining that a new continent had been found which should be named after Amerigo Vespucci. Waldseemüller attached a large printed world map and a small globe, both with the name America used to designate the new island or continent, and drew a strait between the northern and the southern landmasses in the western Atlantic. Whereas the shape of the Atlantic coasts of Africa and the new island or continent in the southwestern Atlantic reproduced the information provided by Portuguese-Genoese world maps that had been circulating in 1502-1504, the outline of India and Indonesia reproduced outdated knowledge that had been made current before the first voyage of Vasco da Gama.

On the 25th of April 1507, this humanist enterprise was published in quarto in two editions at Saint-Dié. ${ }^{10}$ The printer, Walter Ludd, was the nephew of John Ludd, secretary to René II. This edition of the Cosmography of Ptolemy was dedicated to "Divo Maximiliano Caesari semper Augusto" and the following travel account attributed to Vespucci was dedicated to René II. Thus, on the 27th of April, just before Maximilian formally entered Konstanz to open the diet on the 30th of April, in SaintDié, at a distance of approximately $200 \mathrm{~km}$, a very impressive humanist book showing a new continent in the text, on a map and on a globe was issued, and part of these new territories were claimed for Maximilian's heir. In the book's dedication, Maximilian was addressed as Emperor, just as he was asking the German estates to finance his coronation in Italy. Obviously, Maximilian not only issued the broadsheet mentioned previously, which explained the political situation and called for money to finance his expedition to Rome, but made an additional propagandistic effort. The geographic and cartographic publications on "America" would impress the assembled estates and ambassadors with Maximilian's connections to the New World so that the assembly would support him rather than the French king in his quest for the imperial crown. This situation resembled 
the dispute between Charles V and Francis I twelve years later.

In spite of the fantastic descriptions in the Quatuor Navigationes and the outdated representation of India and East India, the map and globe were an especially big success. German humanists copied and recopied Waldseemüller's geographical sketch and immediately sent it to their colleagues. This new promotion was furthered by three additional editions of the Ringmann and Waldseemüller work, which were published on the 29th of August 1507, on the eve of Maximilian's expedition to northern Italy. But in the following years, publication ceased. Waldseemüller left Saint-Dié and returned to Freiburg. On his future maps, he omitted the new name of the new continent. Ringmann published only one further work in Saint-Dié, namely a book for Latin teachers in 1509, and left afterwards for a job as a schoolteacher in Alsace, where he died in 1511. Duke René had already died in an accident in December 1508. Even though Waldseemüller, one of the inventors of America, very soon dropped the name, especially as new maps from the New World that linked the northern and southern parts of the continent had become available, America survived on many printed maps and in the late $16^{\text {th }}$ century, became predominant on geographical charts issued in Northern Europe.

To offer a hypothesis in the debate about the naming of the New World, it may be suggested that from 1506 onwards, German humanists were much more familiar with the voyages of Amerigo Vespucci than with those of Christopher Columbus. This was due to the enormous propaganda efforts of merchant houses from Upper Germany that needed to finance their participation in the fleet of the first Portuguese viceroy to India, As a result, more than twenty editions of the Mundus Novus were issued in just three years. Like his patronage of the arts and printing (Silver, 2008), the hype about Amerigo Vespucci was also used by Maximilian I in order to further his own quest for the imperial crown and title, in opposition to Louis XII of France. Therefore, Maximilian I not only financed a broadsheet explicitly explaining his financial needs to the Diet of Konstanz, but he also must have ordered the propaganda regarding the possible gains to be expected when he was crowned emperor. To this end, Waldseemüller and Ringmann, former students of his personal confessor Reisch at Freiburg, invented a new continent on a map, a globe and explained them in a geographical treatise published at the beginning of the Diet of Konstanz. From 1507 onwards, the familiarity with the name Amerigo Vespucci and the deep impression made by the globe and world map, furthered by Emperor Maximilian I, must have been the reason why German humanist circles stuck with the new name even when its inventor had dropped it.

The extensive impact of Waldseemüller's and Ringmann's naming must to a large extent be attributed to early propaganda for the "Mundus Novus", i.e. to German mercantile interests in Asia. This could also be used by Maximilian I to strengthen his political position and obtain the imperial crown. Thus, the struggle for the Holy Roman Empire and the need for investment in European trade with Asia determined the invention of America.

\section{NOTES}

1. For intensive discussions of this paper and for supplying me with very important information concerning European politics around 1500 I would like to thank Horst Pietschmann.

2. For the cartographical aspects see Gall, 2006; Wolff, München 1992: 111-126; a summary in English of current research: Johnson, 2006: 3-43.

3. For the cartography between 1500 and 1504 see: Martín-Merás, 1993.

4. Raccolta di documenti e studi, part III, vol. 1, p. 153: letter of Alberto Cantino to Hercules I of Ferrara, Rome, 19th of November of 1502 .

5. Vespucci. Petri Francisci de Medicis Salutem plurimam, Paris: F.Baligaut \& J.Lambert, 1503. [11]p. quarto; John Carter Brown Library: CB (3) I:40; Database: European Views of the Americas: 1493 to 1750 , EBSCOhost (accessed March 6, 2014).

6. This edition of the Vespucci letter is preserved at the John Carter Brown Library: H 505 V581 ds (F).

7. John Carter Brown Library: C505 P116a.

8. I would like to thank Ingeborg Wiesflecker-Friedhuber for her advice.

9. See the cartographic study of Lehmann, Cosmographiae introductio.

10. Two editions were published on $25^{\text {th }}$ of April and three editions on $28^{\text {th }}$ of August in 1507. Both in quarto, 167 pages and illustrations by the same printer G. Ludd at Saint-Dié: Waldseemuller. Cosmographiae introductio . . Insuper quatuor Americi Vespucij navigationes. Universales cosmographiae descriptio . . . eis etiam insertis quae Ptholomaeo ignota a nuperis reperta sunt, European Views of the Americas: 1493 to 1750, EBSCOhost (accessed March 21, 2014). For the text see the digitalization of the Library of Congress: http://archive.org/ stream/cosmographiaeint00walduoft/cosmographiaeint00walduoft _djvu.txt (accessed March 21, 2014)

\section{REFERENCES}

Alden, John; Landis, Dennis C. (editors), (1980) European Americana. A Chronological Guide to Works Printed in Europe Relating to the Americas, 1493-1600, vol. 1. The John Carter Brown Library and Readex Books, Providence and New York; available online: Database: European Views of the Americas: 1493 to 1750, European Americana: A Chronological Guide to Works Printed in Europe Relating to the Americas, 1493-1600. http://www.ebscohost.com/archives/general-archives/ european-views-of-the-americas.

Aram, Bethany (2005) Juana the Mad. Sovereignty and Dynasty in Renaissance Europe. The Johns Hopkins University Press, Baltimore-London.

Berchet, Guglielmo (editor), (1892-1893) Raccolta di documenti e studi, part III, 2 vols., Reale Commissione Colombina pel quarto centenario della scoperta dell'America, Rome.

Bethencourt, Francisco and Egmond, Florike (editors), (2007) Correspondence and Cultural Exchange in Early Modern Europe. Cambridge University Press, Cambridge. 
Bouza, Fernando (2001) Corre manuscrito. Una historia cultural del Siglo de Oro. Marcial Pons, Madrid.

Buck, Thomas Martin (2008) "'Des heiligen Reichs und deutscher Nation Nothdurft und Obliegen'. Der Konstanzer Reichstag von 1507 und die europäische Politik". Schriften des Vereins für Geschichte des Bodensees 126: 35-57.

de Vivo, Filippo (2007) Information and Communication in Venice: Rethinking Early Modern Politics. Oxford University Press, Oxford.

Delgado Gómez, Angel (1993) "The earliest European Views of the New World Natives". In Early Images of the Americas. Transfer and Invention, edited by Williams, Jerry M. and Lewis, Robert E., The University of Arizona Press, Tuscon: 3-20.

Digot, Auguste (1856) Histoire de Lorraine, vol. 4., Vagner, Nancy. Eisenstein, Elizabeth (1983) The printing revolution in Early Modern Europe. 2 vols., Cambridge University Press, Cambridge.

Elliott, John H. (1970) The Old World and the New. Cambridge University Press, Cambridge.

Erhard, Andreas; Ramminger, Eva (1998) Die Meerfahrt, Balthasar Springers Reise zur Pfefferküste. Haymon, Innsbruck.

Gall, Wolfgang M. (2006) "Martin Waldseemüller. Leben und Wirken”. In Neue Welt \& Altes Wissen. Wie Amerika zu seinem Namen kam. Begleitbuch zur Ausstellung, edited by Asche, Susanne and Gall, Wolfgang M., Fachbereich Kultur der Stadt Offenburg, Offenburg: 39-44.

Gil, Juan (1982) "Pedro Mártir de Anglería, intérprete de la cosmografía colombina". Anuario de Estudios Americanos 39: 487-502.

Gil, Juan (1989) Mitos y utopías del descubrimiento. 2 vols., Alianza, Madrid.

Gil, Juan; Varela, Consuelo (editors), (1984) Cartas de particulares a Colón y relaciones coetáneas, Alianza, Madrid.

Grafton, Anthony (1992) New worlds, ancient texts. The Power of Tradition and the Shock of Discovery, Harvard University Press, Cambridge/Mass.-London.

Häbler, Konrad (1903) Die überseeischen Unternehmungen der Welser und ihrer Gesellschafter. C.L. Hirschfeld, Leipzig.

Hirsch, Rudolf (1976) "Printed Reports on the Early Discoveries and their Reception". In First Images of America. The Impact of the New World on the Old, edited by Chiapelli, Fredi; Allen, Michael J.B. and Benson, Robert L., vol. 2., University of California Press, Berkeley: 537-558.

Infelise, Mario (2002) Prima dei giornali, Alle origini della pubblica informazione (secoli XVI e XVII). Laterza, Roma-Bari.

Johnson, Christine R. (2006) "Renaissance German Cosmographers and the Naming of America". Past and Present, 191: 3-43.

Lehmann, Martin (2010) Die Cosmographiae Introductio Matthias Ringmanns und die Weltkarte Martin Waldseemüllers aus dem Jahr 1507. Ein Meilenstein frühneuzeitlicher Kartographie. Martin Meidenbauer, München.

Lunardi, Ernest; Magioncalda, Elisa and Mazzacane, Rosanna (1988) La scoperta del nuovo mondo negli scritti di Pietro Martire d'Anghiara. Istituto poligrafico e zecca dello Stato, Libreria dello Stato, Roma: 92-95.

Milanesi, Marica (1992) "Arsarot o Anian? Identità e separazione tra Asia e Nuovo Mondo nella cartografia del Cinquecento (1500-1700)". In Il Nuovo Mondo nella coscienza italiana e tedesca del Cinquecento, edited by Prosperi, Adriano and Reinhard, Wolfgang, Il Mulino, Bologna: 19-50.
O’Gorman, Edmundo (1958) La invención de América: investigación acerca de la estructura histórica del nuevo mundo y del sentido de su devenir. UNAM, México.

Pagden, Anthony (1993) European Encounters with the New World: From Renaissance to Romanticism. Yale University Press, New Haven.

Perrone-Moisés, Leyla (1996) "O Brasil "descoberto" pelos Franceses”. Revista Universidade São Paulo, 30 (Junio-Agosto): 84-93.

Pieper, Renate (2000) Die Vermittlung einer neuen Welt. Amerika im Kommunikationsnetz des habsburgischen Imperiums (1493-1598). Von Zabern, Mainz.

Pietschmann, Horst (2007) "Bemerkungen zur 'Jubiläumshistoriographie' am Beispiel '500 Jahre Martin Waldseemüller und der Name "Amerika"". Jahrbuch für Geschichte Lateinamerikas 44: 367-389.

Rumeu de Armas, Antonio (1989) Libro copiador de Cristóbal Colón. Correspondencia inédita con los Reyes Católicos sobre los viajes a América. Estudio histórico-crítico y edición. 2 vols., Testimonio, Madrid.

Sanz, Carlos (1959) El nombre América. Libros y mapas que lo impusieron. Descripción y crítica histórica. Libreria General Victoriano Suárez, Madrid.

Silver, Larry (2008) Marketing Maximilian. The Visual Ideology of a Holy Roman Emperor. Princeton University Press, PrincetonLondon.

Tewes, Götz-Rüdiger (2011) Kampf um Florenz. Die Medici im Exil. Böhlau, Köln.

Vespucci (1503) "Petri Francisci de Medicis Salutem plurimam. F.Baligaut \& J.Lambert, Paris. [11] p. quarto; John Carter Brown Library: CB (3) I:40”. European Americana: A Chronological Guide To Works Printed In Europe Relating To The Americas, 1493-1600, European Views of the Americas: 1493 to 1750, EBSCOhost, viewed March 6, 2014. For the text see the digitalization of the University of Freiburg: Vespucci (1505) De ora antarctiqua per regem portugalliae pridem inventa. Strassburg: M.Hupfuff, [11] p.; illustration; quarto.

Vogel, Klaus (1992) "Amerigo Vespucci und die Humanisten in Wien". Pirckheimer Jahrbuch 7: 53-104.

Waldseemüller (1507) "Cosmographiae introductio . . . Insuper quatuor Americi Vespucij navigationes. Universales cosmographiae descriptio . . . eis etiam insertis quae Ptholomaeo ignota a nuperis reperta sunt. G.Lud, St. Die 25 Apr. 1507. [167] p.; diagr.; quarto; Harrisse (BAV) Add.” European Views of the Americas: 1493 to 1750, EBSCOhost (viewed March 21, 2014). For the text see the digitalization of the Library of Congress: http://archive.org/stream/cosmographiaeint00walduoft/ cosmographiaeint00walduoft djvu.txt, viewed March 21, 2014.

Wiesflecker, Hermann (1986) Kaiser Maximilian I.: das Reich, Österreich und Europa an der Wende zur Neuzeit, vol. 5: Der Kaiser und seine Umwelt: Hof, Staat, Wirtschaft, Gesellschaft und Kultur. Oldenbourg München.

Wolff, Hans (1992) "Martin Waldseemüller. Bedeutendster Kosmograph in einer Epochen forschenden Umbruchs". In America. Das frühe Bild der Neuen Welt. Ausstellung der Bayerischen Staatsbibliothek München, edited by Hans Wolff. Prestl, München: 111-126. 